\title{
2009年サモア諸島沖地震津波の米領サモアにおける 津波高さおよび被害の調査
}

\section{A rapid-response field survey of the 2009 Samoa earthquake tsunami in American Samoa}

\author{
${\text { 行谷佑 }{ }^{1} \text {. 越村俊 }{ }^{2} \cdot \text { 西村裕 }^{3} \text {. 中村有吾 }}^{4}$ \\ Gerard Fryer $^{5} \cdot$ Akapo Akapo $^{6} \cdot$ Laura S. L. Kong $^{7}$ \\ Yuichi NAMEGAYA, Shunichi KOSHIMURA, Yuichi NISHIMURA, Yugo NAKAMURA \\ Gerard FRYER, Akapo AKAPO and Laura S. L. KONG
}

\begin{abstract}
A field survey of the 2009 Samoa earthquake tsunami was conducted on Tutuila Island, American Samoa, within a week of the event. At the western end of the island, the largest runup height was measured to be $16.3 \mathrm{~m}$ and almost all buildings were completely destroyed and/or washed away. In the east, runup or inundation heights were smaller (2-6 $\mathrm{m}$ ), but buildings were severely damaged. At Pago Pago, main town of the island, inundation heights were around 4.5 $\mathrm{m}$, and inundation limit is about $600 \mathrm{~m}$ from the coastline. The tsunami arrived 5-10 minutes after the mainshock. The death toll was low, because federal and territorial governments had together carried out an extensive public education program to explain tsunami hazard.
\end{abstract}

\section{1.はじめに}

2009年9月 29 日 17 時 48 分頃（UTC），南太平洋のサモ ア諸島沖のトンガ海溝付近で, Mw8.1 (Global CMT) の 地震が発生した（図-1 (a)). USGS（オンラインa）によ れば,この地震は正断層型で, トンガ海溝において沈み 込む太平洋プレート内で発生した地震であった。震源の 深さは $18 \mathrm{~km}$ である。震源から約 $200 \mathrm{~km}$ 以内の範囲には, 震源域を取り囲むように米領サモア，サモア独立国，お よびトンガ国が存在し，それぞれで強い摇れを感じた.

この地震に伴い津波が発生し, Pago Pago（米領サモア） の検潮所で片振幅約 $2.4 \mathrm{~m}$ の津波, およびApia（サモア独 立国）で同 $0.8 \mathrm{~m}$ の津波が観測された。 トンガ国も含めた これらの地域では, 津波により死傷者や建物流失などの 甚大な被害がもたらされた。

一般的に，陸域に遡上した津波の高さや被害について の情報は, 壁に付いた浸水線およびデブリなどの痕跡と, 人々の目撃証言などを頼りに得られる。これらの情報を 沿岸各地で詳細に得ることは, 津波の波源に関する知見 や, 伝播および遡上のメカニズム, 被害の発生過程など

\begin{tabular}{|c|c|c|}
\hline 1 正会員 & 博(工) & $\begin{array}{l}\text { 産業技術総合研究所研究員 活断層・地 } \\
\text { 震研究センター }\end{array}$ \\
\hline 2 正会員 & 博 (工) & 東北大学准教授大学院工学研究科 \\
\hline 3 & 博(理) & 北海道大学助教大学院理学研究院 \\
\hline 4 & 博 (地) & $\begin{array}{l}\text { 北海道大学理学研究院研究員大学院理学 } \\
\text { 研究 }\end{array}$ \\
\hline 5 & Ph.D & Pacific Tsunami Warning Center, NOAA \\
\hline 6 & & $\begin{array}{l}\text { National Weather Service, NOAA, American } \\
\text { Samoa }\end{array}$ \\
\hline 7 & $\mathrm{Ph} . \mathrm{D}$ & $\begin{array}{l}\text { International Tsunami Information Center, } \\
\text { UNESCO/IOC-NOAA }\end{array}$ \\
\hline
\end{tabular}

を理解する上で重要である。しかしながら, これらの情 報は時が経つにつれ急速に劣化が生じ, 後になるほど判 然としない証拠となってしまう.

このため，できるだけ速やかに現地調査を行うことで， 沿岸各地の津波の高さや被害の状況などを把握する必要 があった，そこで, 本研究では, 津波来襲直後に米領サ モアのTutuila島で現地調査を行い, 津波高さや被害状況 の調査を行った。なお,この島ではJaffeら（2010）や USGS（オンライン b) による調査結果もあるので, そち らも参照されたい.

\section{2. 調査内容}

\section{(1) 調查地および調查日程}

米領サモア最大の島である Tutuila 島は人口約 5.5 万人 で，東西約 $30 \mathrm{~km}$ に延びる細長い島である．われわれは 地震発生の6日後である2009年10月5日から8日にかけ ての4日間，この島を全島にわたり津波調査を行った。

調査日程が限られていることから, 効率的な調査スケ ジュールを組む必要がある。このため, 調査前に津波の 伝播計算を行い, 計算波高分布と人口分布とを比較する ことで, 島の中での被害甚大地域を予測した (Koshimura, オンライン).この他, DigitalGlobe社によ る津波来襲直後の衛星写真も入手し, 被害を受けた地域 を検討した。

このように事前に調査すべき地点を検討したことによ り, 効率的な調査スケジュールを組むことができた.こ の結果, 調査を行った地点は 50 地点に及んだ. 

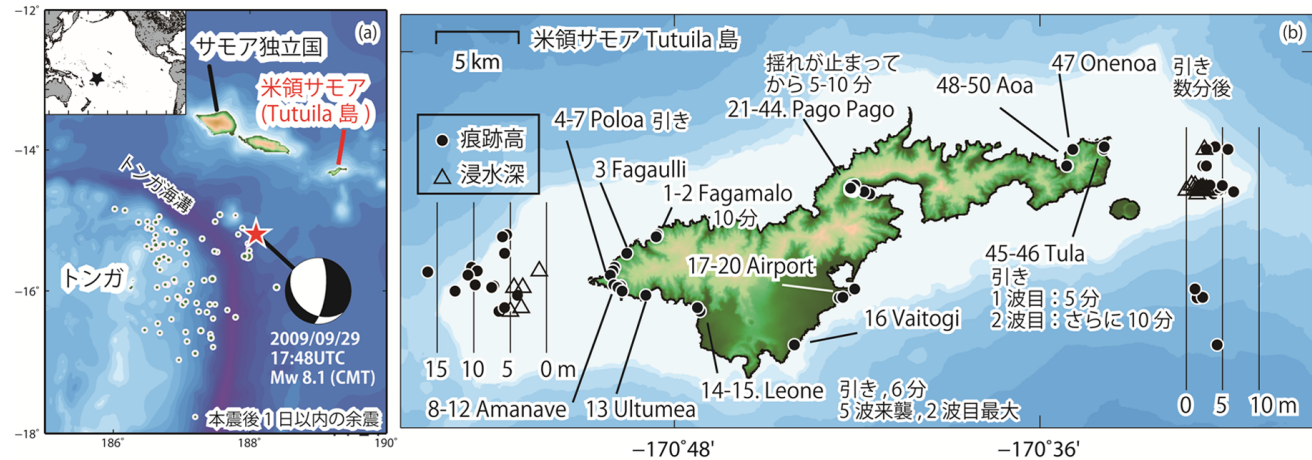

図-1（a）震源域の位置执よび地震のメカニズム解.（b）本調査で行った津波痕跡高の調查結果．地形データはNOAA（オンライン） を用いた。「引き」とあるのは最初海面が引いた旨の証言が得られた地点を表し，時間は地震発生から1波目（押し波）が到達 するまでの時間を表す．地点 1 ～15は左側のグラフを，地点 $16 〜 50$ は右側のグラフを参照されたい.

\section{（2）調査項目}

まず，壁に残された浸水線や地面に残されたデブリと いった津波の痕跡を探した。この他，現地の復旧作業に 支障をきたさない程度に住民から聞き取り調査を行い, 津波の高さなどに関する情報を収集した。これらの情報 を基に，海面を基準にしてトータルステーションにより 痕跡高や浸水深（地面からの高さ）を測定した。ここで 痕跡高とは，津波来襲時の海面からの高さである浸水高 や遡上高を意味する。

痕跡高についてはPago Pagoにおける検潮記録を用い て，津波来襲時と測定時の潮位補正を行った。ただし， 後述のUltumeaおよびAmanaveにおいては，測定時の潮 位が欠測であったために，推算潮位を用いて補正した。

測定值の信頼性については，首藤・卯花（1984）を参 考に，各測定值に対して4段階の信頼度を評価した。た だし，今回の測定はトータルステーションを用いている ことから測定誤差は無視しうるものと考えられるため, 痕跡などの信頼性を基に信頼度を評価した。すなわち， 津波の痕跡が明瞭であるか，あるいは住民の証言が具体 的である場合にはもっとも信頼できる意味の信頼度 $\mathrm{A}$ を 与えた。痕跡がやや不明瞭ながら，住民の証言がそれを 裏付けるものを信頼度 $\mathrm{B}$ とした。痕跡が比較的不明瞭で かつ住民の証言も具体性を欠く，あるいは得られなかっ た場合には信頼度 $\mathrm{C}$ とた。その他，台風や高潮などに よる痕跡と区別がつかないような場合に信頼度 Dとした （本調査では信頼度Dに該当するデー夕はなかった.）。

このほか, 建物の被害状況についても調査を行った。 住民からは，地震発生時，津波に対してどのような避難 行動をしたかなどについても聞き取り調査を行った。

\section{3. 調査結果}

痕跡高や浸水深についてまとめたものを図-1（b）およ

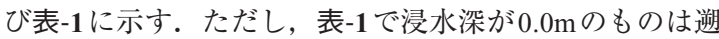

上高を意味し，それ以外は浸水高を意味する。これによ れば，震源域に面したTutuila島西部（Fagamaloから Leoneにかけて）でおおよそ $5 \mathrm{~m}$ 以上の痕跡高が測定され た。とくに島西端部では $10 \mathrm{~m}$ を越える地点が存在し，最 大の高さはPoloaで $16.3 \mathrm{~m}$ を測定した。一方，島の中部や 東部（VaitogiからAoaにかけて）ではおおむね $5 \mathrm{~m}$ 以下 の浸水高および遡上高であり，島西部に比べ津波の高さ は小さかった。聞き取り調査により，いずれの地点も地 震による建物被害はほとんどないことから，被害のほと んどは津波より生じたと考えられる。以下に各地の調査 結果を記す。なお, Poloa, Amanave，およびLeoneでは， U.S. Army Corps of Engineers（2006）による地形図を用い た（図-2，3，および4）.

\section{（1）各地の痕跡高および被害}

a) Fagamalo（地点 1-2）

津波の浸水に伴うデブリが確認され，5.5-6.0mの遡上 高が測定された。そのデブリの位置まで津波が浸水した ことが証言からも得られた。ここでは全壊や流失した家 屋は無かったが，いくつかの家屋では津波による破損が 見られた．地震発生後 10 分程度で津波が来襲した。

\section{b) Fagaulli（地点3）}

石垣の途中にデブリが存在し，その石垣よりも海側に 位置する木が，そのデブリの高さまで枝が枯れたり折れ たりしていた。デブリの高さを測定したところ，遡上高

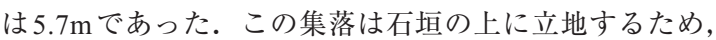
津波による被害はなかった。

\section{c) Poloa (地点 4-7)}

この集落では，本調査で最も大きな痕跡高を記録した。 すなわち, 地点6では崖の上に生える植物が津波により 枯死した様子が明瞭に観察され（図-2, 写真-1 (a))，遡 上高は $16.3 \mathrm{~m}$ と測定された。このほか，デブリによる痕 跡（地点 4 および 7 ）や教会の内壁に残された浸水線（地 点5）などから 9.5-10.9mの痕跡高が測定された。この周 
表-1 津波痕跡高調査結果

\begin{tabular}{|c|c|c|c|c|c|c|c|}
\hline No. & 地点名 & 緯度, 度 & 経度, 度 & 浸水深,m & 痕跡高,m & 信頼度 & 主な証拠 \\
\hline 1 & Fagamalo & -14.297330 & -170.809520 & 0.0 & 5.5 & A & DB \\
\hline 2 & Fagamalo & -14.298400 & -170.809900 & 0.0 & 6.0 & B & DB \\
\hline 3 & Fagaulli & -14.307211 & -170.826173 & 0.0 & 5.7 & A & DB \\
\hline 4 & Poloa & -14.314650 & -170.832900 & 0.0 & 10.1 & $\mathrm{~A}$ & DB \\
\hline 5 & Poloa & -14.316501 & -170.833735 & 1.0 & 9.5 & A & WM \\
\hline 6 & Poloa & -14.317260 & -170.834200 & 0.0 & 16.3 & A & BB \\
\hline 7 & Poloa & -14.318963 & -170.835087 & 0.0 & 10.9 & A & DB \\
\hline 8 & Amanave W. & -14.324100 & -170.833070 & 0.0 & 9.8 & A & ER \\
\hline 9 & Amanave C. & -14.324620 & -170.829620 & 0.0 & 7.3 & A & DB \\
\hline 10 & Amanave C. & -14.325360 & -170.830520 & 3.3 & 7.8 & A & BB \\
\hline 11 & Amanave $\mathrm{C}$. & -14.325560 & -170.830840 & 4.6 & 7.6 & A & BB \\
\hline 12 & Amanave E. & -14.327240 & -170.828690 & 0.0 & 12.4 & A & DB \\
\hline 13 & Ultumea & -14.329490 & -170.815600 & 0.0 & 4.0 & A & DB \\
\hline 14 & Leone & -14.336172 & -170.787553 & 3.5 & 5.7 & A & WA \\
\hline 15 & Leone & -14.338093 & -170.786106 & 4.9 & 6.4 & $\mathrm{~A}$ & WA \\
\hline 16 & Vaitogi & -14.355940 & -170.734450 & 0.0 & 4.2 & A & DB \\
\hline 17 & Airport & -14.331050 & -170.709880 & 0.0 & 1.6 & A & DB \\
\hline 18 & Airport & -14.330990 & -170.709430 & 0.0 & 1.7 & A & DB \\
\hline 19 & Airport & -14.330740 & -170.707760 & 0.0 & 2.3 & A & DB \\
\hline 20 & Airport & -14.326390 & -170.701310 & 0.0 & 1.4 & A & DB \\
\hline 21 & Pago Pago & -14.275600 & -170.693131 & 1.5 & 3.6 & $\mathrm{~A}$ & WM \\
\hline 22 & Pago Pago & -14.274529 & -170.696233 & 0.0 & 6.6 & $\mathrm{~A}$ & DB \\
\hline 23 & Pago Pago & -14.273844 & -170.701940 & 0.0 & 4.8 & A & DB \\
\hline 24 & Pago Pago & -14.273899 & -170.702780 & 1.9 & 4.4 & A & WM \\
\hline 25 & Pago Pago & -14.273306 & -170.703188 & 2.3 & 4.5 & A & WM \\
\hline 26 & Pago Pago & -14.273380 & -170.703226 & 2.5 & 4.6 & $\mathrm{~A}$ & WM \\
\hline 27 & Pago Pago & -14.273559 & -170.703285 & 1.7 & 4.6 & A & WM \\
\hline 28 & Pago Pago & -14.273584 & -170.703840 & 1.2 & 4.6 & A & WM \\
\hline 29 & Pago Pago & -14.273810 & -170.704043 & 0.1 & 4.1 & B & WA \\
\hline 30 & Pago Pago & -14.272425 & -170.703792 & 2.4 & 4.5 & A & WM \\
\hline 31 & Pago Pago & -14.271290 & -170.702990 & 1.4 & 5.1 & A & WM \\
\hline 32 & Pago Pago & -14.271010 & -170.701460 & 0.8 & 3.2 & B & WA \\
\hline 33 & Pago Pago & -14.273700 & -170.702090 & 2.4 & - & A & WM \\
\hline 34 & Pago Pago & -14.273800 & -170.702850 & 2.1 & - & $\mathrm{A}$ & WM \\
\hline 35 & Pago Pago & -14.273530 & -170.702900 & 2.4 & - & A & WM \\
\hline 36 & Pago Pago & -14.273470 & -170.703020 & 2.3 & - & A & WM \\
\hline 37 & Pago Pago & -14.273350 & -170.703140 & 2.4 & - & $\mathrm{A}$ & WM \\
\hline 38 & Pago Pago & -14.273300 & -170.703380 & 1.7 & - & $\mathrm{A}$ & WM \\
\hline 39 & Pago Pago & -14.273740 & -170.703280 & 2.1 & - & A & WM \\
\hline 40 & Pago Pago & -14.273750 & -170.703700 & 1.2 & - & A & WM \\
\hline 41 & Pago Pago & -14.273620 & -170.703830 & 1.5 & - & A & WM \\
\hline 42 & Pago Pago & -14.273310 & -170.703990 & 1.8 & - & A & WM \\
\hline 43 & Pago Pago & -14.273130 & -170.703220 & 2.8 & - & A & WM \\
\hline 44 & Pago Pago & -14.272660 & -170.703720 & 2.0 & - & A & WM \\
\hline 45 & Tula & -14.251966 & -170.564962 & 2.5 & 5.8 & A & WM \\
\hline 46 & Tula & -14.250678 & -170.564680 & 0.0 & 4.0 & $\mathrm{C}$ & BB \\
\hline 47 & Onenoa & -14.252001 & -170.581999 & 0.0 & 2.7 & $\mathrm{C}$ & WA \\
\hline 48 & Aoa & -14.260721 & -170.585117 & 0.0 & 2.3 & A & DB \\
\hline 49 & Aoa & - & - & 0.0 & 2.4 & A & DB \\
\hline 50 & Aoa & -14.260887 & -170.585285 & 0.0 & 2.6 & $\mathrm{C}$ & WA \\
\hline
\end{tabular}

証拠欄で，DB，WM，WA，BB，およびERはそれぞれデブリ，浸水線，目撃証言， 植物の折れや枯死, および土壤浸食を意味する。またNo.49の位置はNo.48の位置 から海岸方向に約 $4 \mathrm{~m}$ 程度離れた所である.

辺では写真-1（b）にあるようにほとんどの建物が破壊・ 流失され，壊滅的な被害を受けた。聞き取り調査によれ ば，最初海面が引いた後，津波が来襲した。

\section{d) Amanave（地点 8-12）}

Poloaの南に位置するAmanaveでは, 浸水限界の位置 情報をGPSにより測量した（図-3）。浸水限界の認定は, 急斜面上では写真-2で示されるように土壌浸食および植 生ダメージなどに基づき, 緩斜面および平坦地ではデブ リや堆積物の分布に基づいた。その結果，最大で $250 \mathrm{~m}$ 程度内陸に浸水し, 遡上高は7.3-12.4mであることがわか

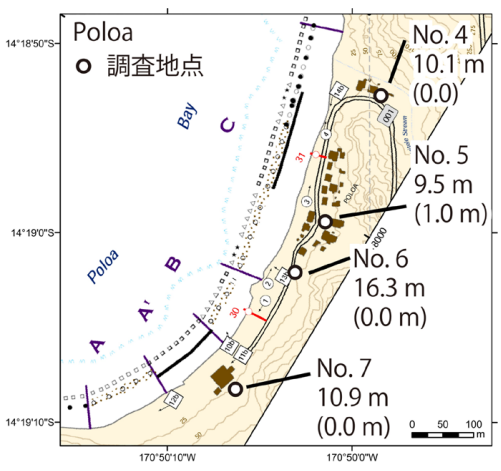

図-2 Poloaでの津波痕跡高測定位置. 地点番号の下の数值は 痕跡高を表し, 括弧内の数值は浸水深を表す. 以下, 図-3，および4も同様である.

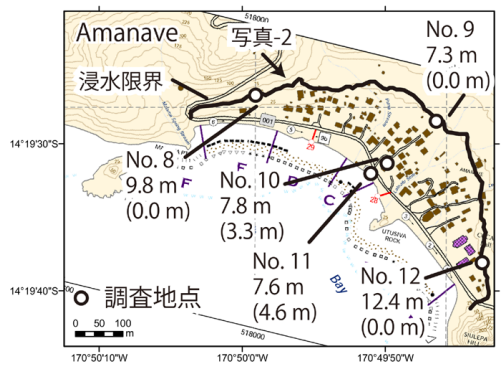

図-3 Amanaveでの津波痕跡高測定位置および浸水限界

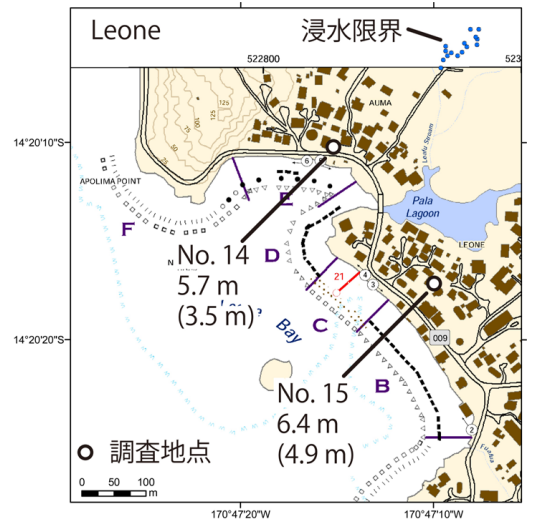

図-4Ｌeoneでの津波痕跡高測定位置および浸水限界
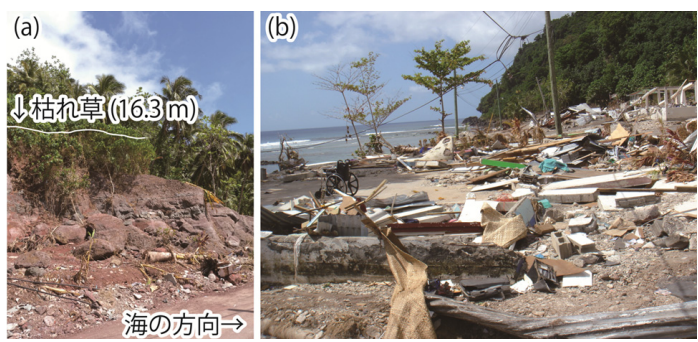

写真-1（a）最大遡上高を記録したPoloaの状況（地点6）（b） Poloaでの被害の様子. 


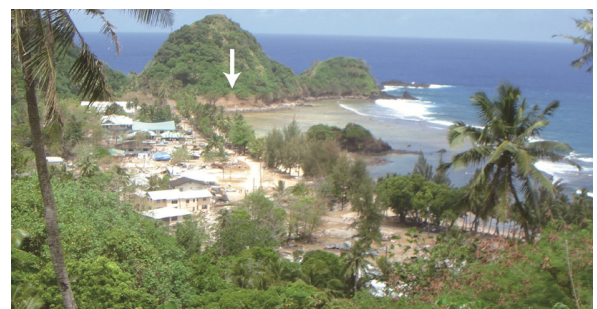

写真-2 図-3の矢印部から撮影したAmanaveの様子．矢印部は 土壌浸食を表す (本文参照).

った（地点 $8 ， 9 ， お よ ひ ゙ 12 ） 。$ 浸水域中央部に位置する 地点 10 および 11 では，木の枝の損傷状況（枝折れ，樹 皮はげ）から 7.6-7.8mの浸水高であることがわかった.

e) Ultumea（地点 13）

この集落では, 浸水限界付近にデブリが堆積しており, $4.0 \mathrm{~m}$ の遡上高が測定された.

\section{f) Leone (地点 14-15)}

聞き取り調査によると, 津波は全部で 5 回来襲し，こ のうち 2 番目の波が最大で，このとき家屋の 1 階と 2 階の 間の庇まで海水が上昇した（写真-3, 図-4, 地点 14).こ こでの浸水高は $5.7 \mathrm{~m}$ であった。このほか, 津波が浸水し たので木の上に昇り難を逃れた住民がおり，それによれ ば $6.4 \mathrm{~m}$ の浸水高であった（地点 $15 ）$.

デブリの分布などから浸水限界を測量したところ（図4), 海岸線から $250 \mathrm{~m}$ 程度奥まで浸水したことがわかっ た.この集落の中心には小さな河川（沼に近い）が存在 するが，この沿岸での建物の全壊・流失が激しかった. しかし, 浸水域内で破壊や流失を免れた建物も混在した.

聞き取り調査によれば，まず海面が引き，その後押し 波が来襲した。地震発生から押し波来襲までは，6分程 度の時間であった。

g) Vaitogi (地点 16)

浸水限界付近にデブリが堆積しており，4.2mの遡上高 が測定された。

\section{h) Airport（地点 17-20)}

津波来襲の同日に撮影されたDigitalGlobe社による衛 星写真に, 津波が空港の滑走路に浸水し，デブリが残さ

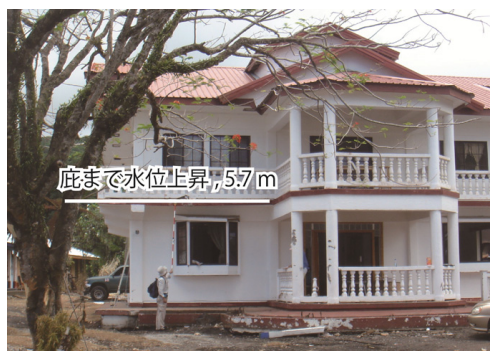

写真-3 Leoneにおける家屋の浸水状況（地点 14）
れた様子が写されている.デブリの位置は浸水限界と考 えられ，空港当局に許可を戴き滑走路内で遡上高の調査 を行った。その結果が図-5であり，1.4-2.3mの遡上高で あった。

\section{i) Pago Pago（地点 21-44）}

この集落は米領サモア最大の町であり，建物や人口の 密度が高い地域である。海辺に近い所ほど，建物の全壊 および流失が激しく，調査時は腐敗臭がひどかった。

ここでは，残された浸水線や目撃証言などによる痕跡 高を高密度に測定した。また，デブリの位置を踏査する ことにより，浸水限界の位置を測定した。

その結果が図-6である。津波は最大で $600 \mathrm{~m}$ 程度内陸 にまで浸水した。痕跡高は3.2-6.6mに及び，浸水域の中 央部ではおおむね $4.5 \mathrm{~m}$ 程度の浸水高であった．浸水深は $2 \mathrm{~m}$ 程度であった。ただし，図-6の中央に走る道路よりも 海側では, 建物の流失が激しく, 浸水線等が確認しにく い状況であった。建物の被害については，越村ら（2010） に詳しい。なお，聞き取り調査によれば，地震の摇れが 止まってから5-10分で津波が来襲した。

\section{j） Tula（地点 45-46）}

島東部に位置するこの集落では，壁に残された浸水線 から $5.8 \mathrm{~m}$ の浸水高および $2.5 \mathrm{~m}$ の浸水深を測定した. 破 壊を受けた建物が多数存在し，地面にはサンゴの破片や

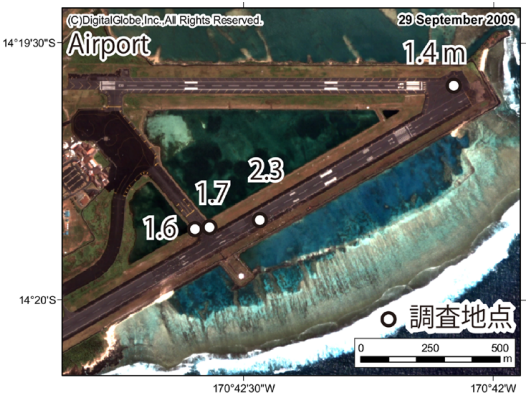

図-5 Airportでの津波遡上高測定位置. 地点名は省略
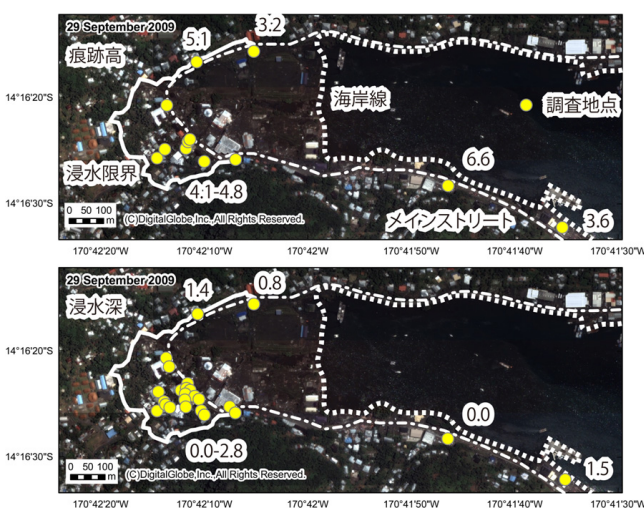

図-6 PagoPagoでの津波痕跡高測定位置および浸水限界. 数

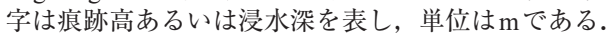


磁，砂などが大量に残っていた，聞き取り調査によれば， 最初海水は引き, 地震の約 5 分後に第 1 波が来襲し, さ らに 10 分後に第 2 波が来襲した。第 1 波はゆっくりとた んだん水が上がってくるように来襲した.

\section{k) Onenoa（地点 47）}

聞き取り調查による浸水限界での高さを測量すると, $2.7 \mathrm{~m}$ の遡上高であった。ここでは, 最初に海水が引き, 地震の数分後に第 1 波が来襲した.

\section{I）Aoa（地点 48-50）}

聞き取り調査や残されたデブリの位置などから，2.3$2.6 \mathrm{~m}$ の遡上高であった.

\section{（2）住民の避難行動}

米領サモアの Tutuila島では，大きな津波により建物な どが甚大な被害を受けた。これに対し，死者の数は比較 的少なかった，たとえば，同島でもっとも大きな津波が 襲った島西端のPoloaでは, 死者は1名にとどまった。こ のような傾向は他の集落でも見られ，同島の人口約 5.5 万人のうち, 死者数は 34 名であった.

比較的死者数が少なかった理由として，この津波の来 襲の直前に行われた啓蒙活動が挙げられる. 現地当局 （U.S. National Weather Service）は，津波来襲の数ヶ月前 に，津波に関する教育活動を全島にわたって行っていた. その中で, 津波の脅威に関する知識と, 強い摇れを感じ たら直ちに高台に逃げるという教訓を普及させた。

実際，われわれが聞き取り調查を行うと，「以前，地 震を感じたら高台に逃げよ，と教えられたのですぐに高 台に逃げた」と答える住民がほとんどであった，もちろ ん, ラジオ放送を通じての避難の呼びかけや, 津波来襲 が現地時間で深夜でなく朝方であったことも, 死者数が 抑えられた要因の 1 つではあるが, 高台へ避難すること が根付いたことが，もっとも大きな要因であったと考え られる.

ところで，2009年10月7日22:03（UTC）にVanuatu沖 でMw7.6（USGS）の地震が発生し, PTWCは米領サモ アに津波警報を発令した，当時われわれはLeoneで調査 を行っている時であり，津波警報を受けて教会の鐘が鳴 り続けた。津波来襲予定時刻まで数時間あることが National Weather Serviceによるラジオ放送にて繰り返し 伝えられていた。多くの住民はすぐに避難行動に移り， 車で避難を行う住民が多く, 道路が啮滞している所もあ った，われわれを含め住民が地震を感じることはなかっ たが，それにも関わらず多くの住民が避難したことは， 地震が無くとも津波が来襲する可能性がある, という知 識を住民が正しく理解している結果であろう.

\section{4. おわりに}

本調査により次の知見が得られた（1）震源域に直面 するTutuila島西端では最大で $16.3 \mathrm{~m}$ の遡上高が測定され た。一方, 島東端でも最大で $6 \mathrm{~m}$ 程度の浸水高が測定さ れた（2）ほとんどの集落で建物などの流失および全壊 被害が甚大であり, 特に島西部の集落はほほ壊滅状態で あった。（3）津波はまず引き波から始まり，地震発生か ら5-10分程度で第 1 波が来襲したことがわかった。(4) 建物被害の割に死者数は少なかった. 調查の結果, 現地 行政機関による啓蒙活動やラジオ放送を通じての避難の 呼びかけのおかげで, 地震直後に高台に避難する行動が 根付いていたことがわかった.

謝辞：本研究の一部はJST ・ JICA及びRISTEK・LIPI間 の地球規模課題対応国際科学技術協力事業, および平成 20 年度産業技術研究助成事業（プロジェクトID： 08E52010a）によって実施されました。

\section{参 考 文 献}

越村俊一 - 郷右近英臣・行谷佑一 - 西村裕一 - 中村有吾 $\cdot G$. Fryer - A. Akapo - L. Kong (2010) : 数值解析. GIS 分析. 衛星画像解析の統合による津波被災地探索技術 - 2009 年サモア諸島沖地震津波災害における実践と検証一, 土 木学会論文集B2 (海岸工学), Vol. 66, 印刷中.

首藤伸夫 - 卯花政孝（1984）：1983 年日本海中部地震津波の痕 跡高, 東北大学工学部津波防災実験所研究報告, $1, \mathrm{pp}$. 88-267.

Koshimura, S. (オンライン) : Modeling the Tsunami of 30 September 2009 in Samoa islands, http://www.tsunami.civil. tohoku.ac.jp/hokusai3/J/events/samoa_090930/samoa0930.html, 参照 5-19-2010.

Jaffe, E. B., G. Gelfenbaum, M. L. Buckley, S. Watt, A. Apotsos, A. W. Stevens and B. M. Richmond (2010): The limit of inundation of the September 29, 2009, tsunami on Tutuila, American Samoa, USGS open-file report 2010-1018, $27 \mathrm{p}$.

NOAA（オンライン）：Pago Pago, As 1/3 arc-second MHW Tsunami Inundation DEM, http://www.ngdc.noaa.gov/dem/ showdem.jsp?dem=Pago $\% 20$ Pago\&state=AS\&cell=1/3\%20arcsecond\&vdat=MHW, 参照 5-19-2010.

U.S. Army Corps of Engineers (2006): American Samoa shoreline inventory update III, U.S. Army Corps of Engineers Honolulu District, $74 \mathrm{p}$.

USGS（オンラインa）：Magnitude 8.1 - Samoa Islands region, 2009 September 29 17:48:10 UTC, http://earthquake.usgs.gov/ earthquakes/recenteqsww/Quakes/us2009mdbi.php, 参照 5-192010.

USGS (オンラインb) : USGS Scientists in Samoa and American Samoa Studying Impacts of Recent Tsunami, OctoberNovember 2009, http://walrus.wr.usgs.gov/news/samoareports. $h t m l$, 参照 5-19-2010. 